\title{
PENGEMBANGAN MULTIMEDIA PEMBELAJARAN STATISTIKA BERBASIS ICT DENGAN MODEL BLENDED PROJECT BASED LEARNING
}

\author{
Maylita Hasyim \\ Program Studi Pendidikan Matematika, STKIP PGRI Tulungagung, Jl. Mayor Sujadi Timur No. 7 \\ Plosokandang, Tulungagung, Jawa Timur, 60221, Indonesia \\ Email maylita@stkippgritulungagung.ac.id
}

\begin{abstract}
In the application of online learning, the need for multimedia ICT-based learning is absolutely necessary, one of which is the learning management system (LMS). This study aims to: 1) develop multimedia ICT-based Statistics for Teknik Analisis Data course using the Blended Project Based Learning Model at LMS STKIP PGRI Tulungagung; and 2) testing the feasibility of multimedia ICT-based Statistics for Teknik Analisis Data course using the Blended Project Based Learning Model at LMS STKIP PGRI Tulungagung. This research is a development research with the ASSURE development model, which consists of 6 stages, namely 1) Analyzing students, 2) Setting learning objectives, 3) Choosing strategies, technology, media, and materials, 4) Utilizing media and materials, 5) Requiring the participation of students, 6) Evaluating and revising. This research instrument is completely valid. This research resulted in: 1) video learning; 2) Statistics handout material; and 3) Descriptive Statistics eBook. The results of the validation by media experts and mathematics learning experts state that the multimedia produced is valid. The results of peer research and multimedia learning students have fulfilled the practical aspects.
\end{abstract}

Keywords: multimedia ICT-based learning; Learning Management System (LMS); Blended Project Based Learning, Statistics; elearning

\begin{abstract}
Abstrak
Dalam penerapan pembelajaran daring, kebutuhan terhadap multimedia pembelajaran berbasis ICT mutlak diperlukan, salah satunya adalah learning management system (LMS). Penelitian ini bertujuan untuk: 1) mengembangkan multimedia pembelajaran Statistika Mata Kuliah Teknik Analisis Data Berbasis ICT dengan Model Blended Project Based Learning pada LMS STKIP PGRI Tulungagung; dan 2) menguji kelayakan materi dan produk multimedia pembelajaran Statistika Mata Kuliah Teknik Analisis Data Berbasis ICT dengan Model Blended Project Based Learning pada LMS STKIP PGRI Tulungagung. Penelitian ini merupakan penelitian pengembangan dengan model pengembangan ASSURE, yang terdiri dari 6 tahapan yaitu 1) Analyze learners (analisis karakteristik pebelajar), 2) State objectives (menetapkan tujuan pembelajaran), 3) Select strategi, technology, media, and materials (memilih strategi, teknologi, media dan bahan), 4) Utilize media and materials (memanfaatkan media dan bahan), 5) Require learner participation (melibatkan partisipasi pebelajar), 6) Evaluated and revise (evaluasi dan revisi). Instrumen penelitian ini terdiri dari lembar validasi ahli, angket penilaian mahasiswa dan lembar penilaian teman sejawat terhadap kepraktisan perangkat pembelajaran. Penelitian ini menghasilkan: 1) video pembelajaran; 2) handout materi Statistika; dan 3) ebook Statistika Deskriptif. Hasil validasi ahli media dan ahli pembelajaran matematika menyatakan bahwa multimedia yang dihasilkan telah valid. Hasil penilaian teman sejawat dan mahasiswa menyatakan multimedia pembelajaran telah memenuhi aspek kepraktisan.
\end{abstract}

Kata kunci: multimedia pembelajaran berbasis ICT, Learning Management System (LMS), Blended Project Based Learning, Statistika, elearning

\section{PENDAHULUAN}

Kecenderungan gaya belajar generasi milenial di era disrupsi teknologi 4.0 merupakan karakteristik belajar bagi generasi milenial yang lebih menyukai melakukan dan mengontrol sendiri atas apa yang sedang dipelajari. Sesuai dengan karakteristik pebelajar ini, maka peran multimedia pembelajaran menjadi sangat vital dalam keberhasilan pendidikan generasi milenial. Secara terminologis, definisi dari "multimedia" adalah bentuk kombinasi dari berbagai media seperti gambar, 
teks, animasi, suara, video ataupun lainnya yang terpadu dan sinergis melalui program komputer atau peralatan elektronik lainnya demi pencapaian tujuan tertentu (Surjono, 2017). Dengan demikian, dalam pemenuhan kebutuhan tersebut maka penggunaan multimedia dalam pembelajaran merupakan salah satu alternatif pilihan yang baik agar pembelajaran optimal dan berkesan (Surasmi, 2016).

Salah satu multimedia pembelajaran interaktif adalah e-learning (electronic learning), yang merupakan media pembelajaran yang disajikan secara elektronik dan media berbasis komputer (Harry, 2007). E-learning yang banyak dikembangkan saat ini dalam bentuk Learning Management System (LMS), dimana salah satu bentuk LMS yang banyak digunakan dan berlisensi open source adalah moodle (Modular Object-Oriented Dynamic Learning Environment). Moodle didefinisikan sebagai perangkat lunak yang telah diproduksi dalam membantu kegiatan belajar berbasis internet dan web dengan prinsip social constructionist pedagogy (Haris \& Dudy, 2004). STKIP PGRI Tulungagung telah memiliki LMS berbasis moodle dengan alamat: https://vlearn.stkippgritulungagung.ac.id/, dengan tampilan beranda disajikan pada Gambar 1 sebagai berikut:

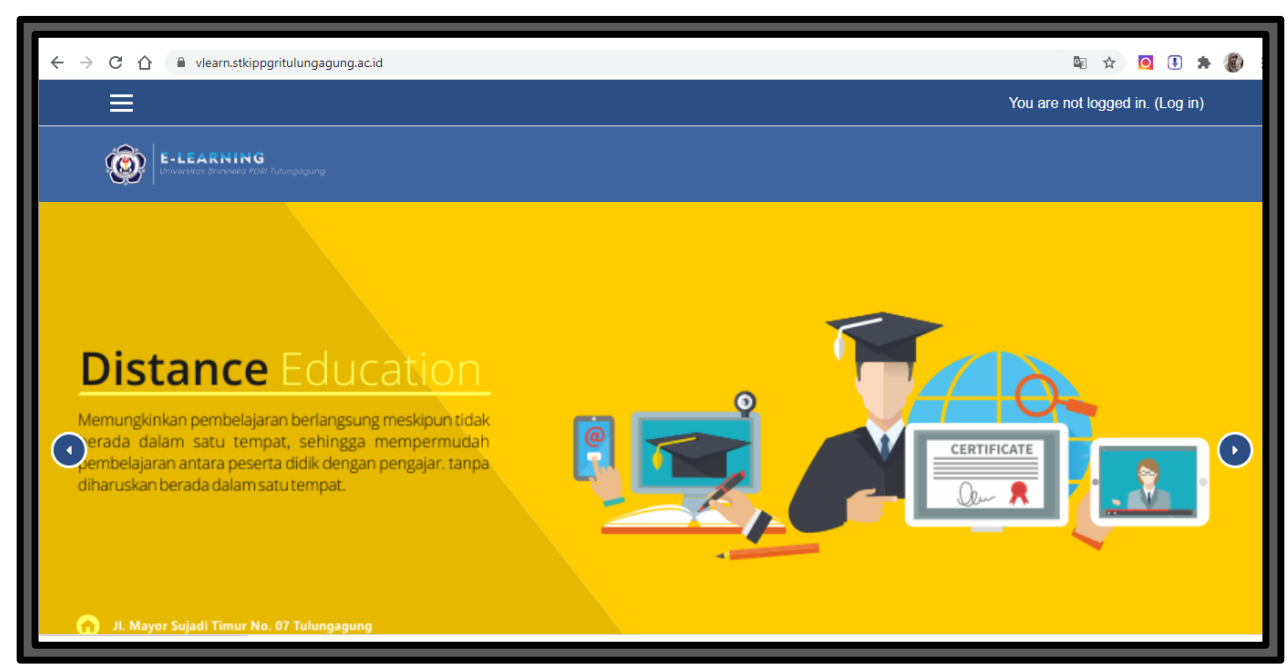

Gambar 1. Tampilan Beranda LMS STKIP PGRI Tulungagung

LMS STKIP PGRI Tulungagung digunakan sebagai media pembelajaran berbasis ICT yang dimanfaatkan oleh dosen dan mahasiswa. Upaya peningkatan kualitas pembelajaran melalui pengembangan multimedia pembelajaran yang disajikan dalam LMS menjadi dasar dilakukannya penelitian di Program Studi Pendidikan Matematika STKIP PGRI Tulungagung.

Pada penelitian ini, multimedia pembelajaran berbasis ICT yang akan dikembangkan pada LMS mata kuliah Teknik Analisis Data adalah pertama, pengembangan video pembelajaran Statistika, yang menggunakan aplikasi Screencast-O-Matic. Screencast-O-Matic adalah sebuah aplikasi berbasis Java yang dapat digunakan untuk membuat screencast pada sistem operasin Windows, Mac dan juga Linux (Priowirjanto et. al., 2013). Screencast-O-Matic merupakan software yang dapat merekam semua media pembelajaran e-learning menjadi video tutorial yang dapat menggambarkan dosen berada dalam suasana kelas dan dapat di-share melalui berbagai media sosial (Dewi, 2016). Multimedia 
pembelajaran lainnya yang dihasilkan adalah handout materi Statistika dan ebook Statistika, dimana buku mata kuliah disajikan pada LMS yang dapat diakses oleh peserta mata kuliah.

Multimedia pembelajaran berbasis ICT ini digunakan dalam model Blended Project Based Learning, dimana orientasi pembelajaran menekankan pada proyek yang diberikan kepada mahasiswa melalui pembelajaran virtual (online) yang dikombinasikan dengan teori yang disampaikan ketika pembelajaran tatap muka. Blended learning merupakan konsep baru dalam pembelajaran dimana penyampaian materi dapat dilakukan di kelas dan online (Bielawski dan Metcalf dalam Husamah, 2014). Semler (dalam Husamah, 2014:11) berpendapat bahwa pengertian blended learning adalah menggabungkan keunggulan e-learning, keunggulan face-to-face, dan praktiknya. Kemudian Graham (dalam (Sari, 2016: 127) menyebutkan defnisi dari blended learning yang sering disampaikan adalah pembelajaran yang menggabungkan dengan media pembelajaran, pembelajaran yang menggabungkan model-model pembelajaran dan teori-teori pembelajaran, dan pembelajaran yang menggabungkan pembelajaran tatap muka (face-to-face) dengan pembelajaran online. Berdasarkan pengertian di atas, maka blended learning merupakan pembelajaran yang menggabungkan e-learning dengan pembelajaran tatap muka yang menggunakan media pembelajaran serta teori-teori pembelajaran dalam proses pembelajarannya.

Project Based Learming sebagai model pembelajaran yang memberikan kesempatan kepada dosen untuk mengelola pembelajaran di kelas dengan melibatkan kerja proyek. Kerja proyek adalah suatu bentuk kerja yang memuat tugas-tugas yang kompleks berdasarkan pada pertanyaan dan permasalahan yang menantang, dan menuntut mahasiswa untuk merancang, memecahkan masalah, membuat keputusan, melakukan kegiatan investigasi, serta memberikan kesempatan kepada mahasiswa untuk bekerja secara mandiri (Wena, 2009 dalam Syafiudin et al., 2016). Dengan demikian, pembelajaran berbasis proyek lebih berpusat pada mahasiswa karena mahasiswa dituntut untuk mengumpulkan dan mengintegrasikan pengetahuan baru. Pengetahuan baru tersebut diperoleh dari hasil proyek mahasiswa yang dibantu oleh dosen, peran dosen dalam pembelajaran ini sebagai fasilitator (Syafiudin Et al, 2016).

Penelitian ini menerapkan konsep pembelajaran yang menggabungkan blended learning dengan project based learning, yang berarti pembelajaran berbasis proyek dikemas dalam bentuk tatap muka dan online melalui media LMS. Model pembelajaran ini disebut "Model Blended Project Based Learning", yang diharapkan mampu memberikan peluang bagi mahasiswa dalam meningkatkan kemampuan berpikir tingkat tinggi (Higher Order Thinking Skill/ HOTS). Pemanfaatan teknologi informasi dalam pengembangan multimedia pembelajaran ini diharapkan dapat menjadi produk inovasi dalam bidang pendidikan dan pembelajaran khususnya di STKIP PGRI Tulungagung yang sesuai dengan karakteristik mahasiswa sebagai generasi milenial.

Berbagai penelitian yang mengembangkan multimedia pembelajaran berbasis ICT telah banyak dilakukan yang dijadikan referensi dalam penelitian ini antara lain: Surasmi (2016) meneliti tentang Pemanfaatan Multimedia Untuk Mendukung Kualitas Pembelajaran; Febrianto Et al. (2017) 
menganlisi penerapan media pembelajaran prezi terhadap hasil belajar siswa kelas X TPHP pada mata pelajaran pengendalian mutu dalam proses pengolahan di SMK Negeri 3 Takalar; (Raharja Et al. 2011) menerapkan model pembelajaran berbasis learning management system dengan pengembangan software moodle di SMA Negeri Kota Yogyakarta; dan Munir (2010) yang menggunakan Learning Management System (LMS) Di Perguruan Tinggi: Studi Kasus Di Universitas Pendidikan Indonesia.

Penelitian sebelumnya yang menerapkan Blended Project Based Learning telah banyak dilakukan yang dijadikan referensi dalam penelitian ini antara lain: Sari (2016) meneliti tentang Blended Learning, Model Pembelajaran Abad Ke-21 Di Perguruan Tinggi; Sumarmi (2012) yang meneliti tentang Model-model Pembelajaran Geografi yang salah satunya yaitu Blended Project Based Learning; dan Syarifudin Et al. (2016) mengembangkan modul geografi pariwisata dengan project based learning untuk materi ekowisata pesisir dan laut di Program Studi S1 Pendidikan Geografi Universitas Negeri Malang.

Sedangkan studi pendahuluan yang telah dilakukan peneliti adalah mengembangkan media pembelajaran berbasis ICT mata kuliah Statistika Matematika I berbasis pembelajaran Daring (Dalam Jaringan) pada media LMS STKIP PGRI Tulungagung yang dilaksanakan pada tahun 2019. Studi pendahuluan ini bekerjasama dengan Universitas Kanjuruhan Malang dalam pelaksanaan pembelajaran daring. Berdasarkan hasil studi pendahuluan ini, maka penelitian ini penting untuk dilakukan sebagai inovasi pembelajaran bagi mahasiswa Program Studi Pendidikan Matematika STKIP PGRI Tulungagung demi peningkatan prestasi belajar.

\section{METODE}

Penelitian ini merupakan penelitian dan pengembangan (research and development/ R\&D) dengan model Pengembangan ASSURE. Model desain dikembangkan dalam 6 tahapan, yaitu: 1) analyze learners, 2) state objectives, 3) select strategi, technology, media, and materials, 4) utilize media and materials, 5) require learner participation, 6) evaluated and revise (Smaldino, Lowther, \& Russell, 2012). Untuk lebih jelasnya dapat dilihat pada Gambar 2.

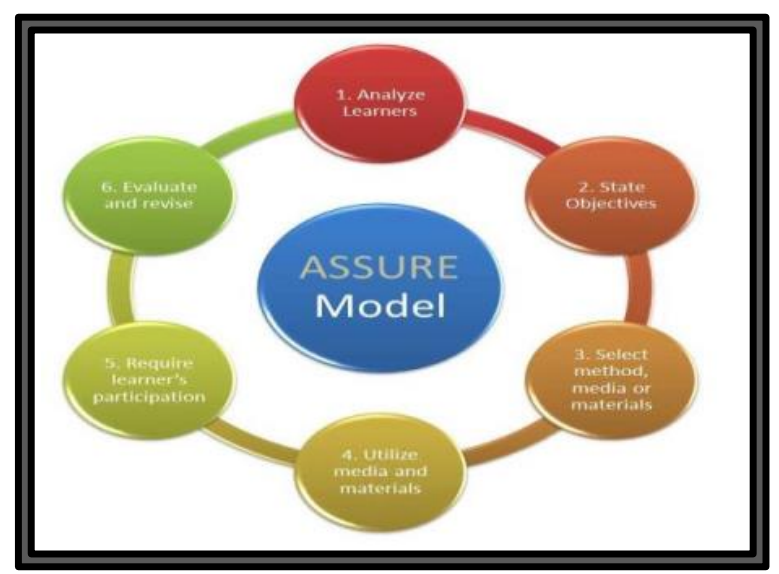

Gambar 2. Model Pengembangan ASSURE 
Berdasarkan bagan pada Gambar 2 maka langkah-langkah pengembangan model dengan desain ASSURE secara rinci dapa dijelaskan berikut ini:

1) Analyze learners (analisis karakteristik mahasiswa): langkah awal yang perlu dilakukan adalah mengidentifikasi karakteristik mahasiswa yang meliputi kemampuan awal mahasiswa yang diperoleh melalui pre-test, terutama tentang Statistika, aksesbilitas mahasiswa dalam menggunakan teknologi (komputer, internet dan pembelajaran online), dan gaya belajar mahasiswa;

2) State objectives (menetapkan tujuan pembelajaran): langkah yang kedua adalah menetapkan tujuan pembelajaran yang didasarkan pada hasil analisis karakteristik mahasiswa. Hasil analisis karakteristik mahasiswa, capaian pembelajaran mata kuliah dan kemampuan akhir yang direncanakan yang telah tercantum dalam kurikulum yang didasarkan pada prinsip Blended Project Based Learning dirumuskan ke dalam Rencana Pembelajaran Semester (RPS) beserta rancangan bahan ajar dan rancangan proyek (tugas) yang akan diberikan kepada mahasiswa selama satu semester;

3) Select method, media, and materials (memilih metode, media, dan bahan ajar): penentuan metode, media, dan bahan ajar didasarkan pada karakteristik mahasiswa dan tujuan pembelajaran serta prinsip belajar dengan blended project based learning tatap muka dan online dalam fasilitas LMS STKIP PGRI Tulungagung;

4) Utilize media and materials (memanfaatkan media dan bahan ajar): tahap ini melakukan validasi/ penilaian ahli yaitu ahli materi pembelajaran dan ahli media pembelajaran, untuk melihat kualitas dan kelayakan model yang telah dibuat;

5) Require learner participation (melibatkan mahasiswa dalam kegiatan pembelajaran): langkah selanjutnya adalah melakukan uji coba terbatas dalam kelompok kecil (1-3 mahasiswa) terhadap multimedia pembelajaran yang dirancang dan teman sejawat dosen Program Studi Pendidikan Matematika;

6) Evaluated and revise (evaluasi dan revisi): Hasil uji coba dianalisis untuk perbaikan multimedia pembelajaran sebelum diterapkan.

Subjek penelitian ini adalah Mahasiswa Program Studi Pendidikan Matematika STKIP PGRI Tulungagung yang menempuh mata kuliah Teknik Analisis Data pada semester genap tahun akademik 2019/2020. Produk yang dihasilkan akan dilihat kevalidan (kelayakan), kepraktisan, dan efektivitasnya. Kevalidan produk dilakukan dengan cara penilaian pakar (ahli). Penilaian paka meliputi pakar pembelajaran, media pembelajaran dan bahan ajar. Data penilaian pakar menggunakan skala Likert dengan rentang 1-5 dengan kriteria sangat kurang (1) sampai dengan sangat baik (5). Hasil ini digunakan untuk melihat kelayakan (kevalidan) produk yang dihasilkan. Untuk melihat kepraktisan produk dilakukan dengan memberikan angket (tertutup dan terbuka) untuk melihat respon teman sejawat dan mahasiswa dalam uji terbatas implementasi model. 
Data hasil uji penilaian pakar (validasi produk) dianalisis dengan menggunakan teknik deskriptif persentase dan kategoris untuk menggambarkan kelayakan model. Pada awalnya skor hasil pengukuran dengan menggunakan angket tertutup dijumlahkan dan diratarata antara hasil skor ahli 1 dengan ahli 2. Kemudian skor tersebut dipersentase dengan menggunakan rumus 1 berikut:

$$
A P=\frac{\text { SkorAktual }}{\text { SkorIdeal }} \times 100 \%
$$

Keterangan:

AP : Angka Persentase

Skor Aktual : Skor yang diberikan oleh validator ahli

Skor Ideal : Skor maksimal hasil kali antara jumlah item dengan skor maksimal masingmasing item.

Angka persentase tersebut selanjutnya dikelompokkan menjadi lima kategori seperti berikut:

Tabel 1. Interval Kategori Validasi Produk

\begin{tabular}{|c|l|}
\hline Interval & Kategori \\
\hline $81-100 \%$ & Sangat Tinggi \\
\hline $61-80 \%$ & Tinggi \\
\hline $41-60 \%$ & Cukup \\
\hline $21-40 \%$ & Rendah \\
\hline $1-20 \%$ & Sangat rendah \\
\hline
\end{tabular}

Berdasarkan kategori persentase di atas, maka model blended project based learning dapat dikatakan layak untuk diujicobakan apabila angka rata-rata persentase minimal mencapai kategori tinggi ( $\geq 61 \%$ ). Uji kepraktisan dilakukan dengan melihat hasil respon teman sejawat dan mahasiswa saat uji terbatas penerapan model.

\section{HASIL}

Produk yang dihasilkan dari penelitian ini adalah: 1) video pembelajaran Statistika, yang menggunakan aplikasi Screencast-O-Matic; 2) handout materi Statistika; dan 3) ebook Statistika, dimana buku mata kuliah disajikan pada LMS yang dapat diakses oleh peserta mata kuliah. Pengembangan multimedia pembelajaran menggunakan tahapan-tahapan dalam model ASSURE:

\section{Analyze learners (analisis karakteristik mahasiswa)}

Kondisi pebelajar atau mahasiswa calon peserta mata kuliah Teknik Analisis Data harus dikenali dan dianalisis sebelum merancang pembelajaran dan menyusun bahan ajar. Dengan adanya analisis raw material peserta didik diharapkan proses pembelajaran dapat berkualitas sesuai dengan 
target capaian pembelajaran mata kuliah (CPMK). Penilaian kualitas pembelajaran ini dapat diidentifikasi melalui indikator pencapaian target selama proses pembelajaran dan hasil belajar pada akhir pembelajaran, dimana penilaian selama proses pembelajaran memiliki porsi yang lebih besar dalam menentukan keberhasilan peserta didik. Dengan demikian, karakteristik mahasiswa yang meliputi tingkat kemampuan berpikir, gaya belajar, kemampuan awal yang dimiliki, dan aksesibilitas mahasiswa terhadap teknologi informasi yang digunakan dalam pembelajaran sangat mempengaruhi ketercapaian peserta didik selama proses pembelajaran. Mata kuliah Teknik Analisis Data ini diikuti oleh mahasiswa Program Studi Pendidikan Matematika semester 6 dari STKIP PGRI Tulungagung. Berikut analisis karakteristik mahasiswa calon peserta mata kuliah Statistika Matematika I disajikan pada Tabel 2:

Tabel 2.

Analisis Raw Material Calon Peserta Mata Kuliah

\begin{tabular}{|l|l|}
\hline \multicolumn{1}{|c|}{$\begin{array}{c}\text { Karakteristik yang } \\
\text { dianalisis }\end{array}$} & \multicolumn{1}{c|}{ Deskripsi Hasil Analisis } \\
\hline $\begin{array}{l}\text { Tingkat Kemampuan } \\
\text { Berpikir }\end{array}$ & $\begin{array}{l}\text { Indeks prestasi (IP) adalah angka yang menunjukkan prestasi atau } \\
\text { kemajuan belajar mahasiswa, sehingga tingkat kemampuan berpikir } \\
\text { mahasiswa dapat dilihat dari nilai IPK. Berdasarkan nilai IPK mahasiswa } \\
\text { pada semester sebelumnya, maka dapat diketahui rata-rata IPK } \\
\text { mahasiswa sebesar 3,37 sehingga tingkat kemampuan berpikir } \\
\text { mahasiswa dikategorikan "baik" (rentang 3,00 - 3,50) }\end{array}$ \\
\hline Gaya Belajar & $\begin{array}{l}\text { Gaya belajar mahasiswa menentukan model dna media pembelajaran } \\
\text { yang akan dirancang. } \\
\text { Gaya belajar dari 62\% mahasiswa adalah gaya belajar visual, sedangkan } \\
\text { 22\% mahasiswa dengan gaya belajar audio dan 16\% sisanya dengan gaya } \\
\text { belajar kinestetik. }\end{array}$ \\
\hline Kemampuan Awal & $\begin{array}{l}\text { Kemampuan awal mahasiswa dapat dilihat dari hasil nilai pretest yang } \\
\text { telah diberikan di awal perkuliahan. Rata-rata kemampuan awal } \\
\text { mahasiswa sebesar 75,6. }\end{array}$ \\
\hline $\begin{array}{l}\text { Aksesibilitas Teknologi } \\
\text { Informasi } \\
\text { (internet dan komputer) }\end{array}$ & $\begin{array}{l}\text { Hampir 70\% mahasiswa telah memiliki laptop atau komputer (PC) dan } \\
\text { semua mahasiswa telah menggunakan smartphone yang selalu } \\
\text { menggunakan paket data untuk mengakses internet. Selain itu, jaringan } \\
\text { wifi di kampus dapat digunakan selama 24jam dengan kecepatan 5mbps. }\end{array}$ \\
\hline
\end{tabular}

\section{State Objectives (Menetapkan Tujuan Pembelajaran)}

Tahap selanjutnya adalah menetapkan tujuan pembelajaran yang dirumuskan dalam bentuk Capaian Pembelajaran Mata Kuliah (CPMK), Kemampuan Akhir yang Direncanakan (KAD), indikator dan materi yang akan disampaikan. Perumusan tujuan pembelajaran didasarkan pada hasil analisis karakteristik mahasiswa yang telah dilakukan pada tahap sebelumnya. Hasil penentuan tujuan pembelajaran pada tahap ini adalah:

a. Capaian Pembelajaran Mata Kuliah (CPMK) Teknik Analisis Data yaitu "Mahasiswa mampu menjelaskan pengetahuan tentang data termasuk informasi yang dikandungnya secara komprehensif dan mengaplikasikan Statistika pada penyelesaian masalah riil di bidang pendidikan melalui prosedur analitik secara secara tepat dan solutif”; 
b. Kemampuan Akhir yang Direncanakan (KAD) mata kuliah Teknik Analisis Data yaitu: 1) Menjelaskan konsep Statistika dan istilah-istilah dalam Statistika; 2) Menyajikan data dalam bentuk Tabel Distribusi Frekuensi; 3) Menyajikan data dalam bentuk grafik (diagram); 4) Menentukan nilai ukuran pemusatan (central tendensi); 5) Menentukan nilai ukuran letak/lokasi; 6) Menentukan nilai ukuran penyebaran; 7) Menjelaskan prosedur pengujian hipotesis statistik; 8) Menjelaskan konsep teknik analisis data; 9) Melakukan pengujian hipotesis uji beda (uji-t); 10) Melakukan pengujian hipotesis analisis variansi; 11) Menentukan persamaan regresi linier.

Hasil analisis karakteristik mahasiswa, penentuan capaian pembelajaran mata kuliah (CPMK) dan kemampuan akhir yang direncanakan (KAD) yang telah tercantum dalam kurikulum yang didasarkan pada prinsip Blended Project Based Learning dirumuskan ke dalam Rencana Pembelajaran Semester (RPS) beserta rancangan bahan ajar dan rancangan proyek (tugas) yang akan diberikan kepada mahasiswa selama satu semester. Dengan prinsip ini diharapkan hubungan antara materi pelajaran, teknologi dan pedagogi memiliki kekuatan dan daya tarik mahasiswa dalam mempelajari Statistika.

\section{Select Method, Media, and Materials (Memilih Metode, Media, dan Bahan)}

Berdasarkan hasil analisis kurikulum yaitu penentuan Capaian Pembelajaran Mata Kuliah (CPMK), Kemampuan Akhir yang Direncanakan (KAD), lalu diturunkan ke dalam konsep materi (pokok bahasan materi) dan juga hasil analisis pebelajar (mahasiswa) maka selanjutnya dapat disusunlah perangkat pembelajaran, bahan ajar, media pembelajaran dalam bentuk multimedia serta sistem penilaian. Rancangan pembelajaran ini menjadi kerangka acuan dasar pengembangan konten pembelajaran mata kuliah Teknik Analisis Data berbasis Blended Project Based Learning. Dalam pengembangan konten pembelajaran diperlukan rancangan pembelajaran yang terdiri dari: 1) perangkat pembelajaran; bahan ajar; multimedia pembelajaran dan sistem penilaian.

Rancangan pembelajaran Teknik Analisis Data meliputi:

\section{Perangkat Pembelajaran}

\section{Rencana Pembelajaran Semester (RPS)}

Komponen dalam RPS meliputi identitas mata kuliah, capaian pembelajaran mata kuliah (CPMK), deskripsi singkat mata kuliah, pustaka (referensi), media pembelajaran, dosen pengampu, Kemampuan akhir yang Direncanakan (KAD), materi pembelajaran, metode/strategi pembelajaran, assesment.

\section{Peta Program}

Komponen dalam Peta Program meliputi identitas mata kuliah, dosen pengampu, capaian pembelajaran mata kuliah (CPMK), deskripsi singkat mata kuliah, sub capaian pembelajaran atau Kemampuan akhir yang Direncanakan (KAD), topik/kajian/pokok bahasan, strategi pembelajaran, objek pembelajaran dan asesmen.

\section{Bahan Ajar}




\section{Handout Materi}

Handout materi disusun pada setiap pokok bahasan. Mata kuliah Teknik Analisis Data berbasis Blended Project Based Learning ini telah disusun 11 (sembilan) handout materi dalam bentuk pdf yang diunggah ke dalam LMS pada setiap pokok bahasan, sehingga mahasiswa dapat mengunduh handout materi kapan pun pada laman LMS.

Ebook

Pada mata kuliah Teknik Analisis Data berbasis Blended Project Based Learning menggunakan 1 ebook ber-ISBN yang berjudul "Statistika Deskriptif", terdiri dari 6 (enam) bab yaitu: Konsep Statistika dan istilah-istilah dalam Statistika, Tabel Distribusi Frekuensi, Grafik (diagram), Ukuran pemusatan (central tendensi), Ukuran letak/lokasi; dan Ukuran penyebaran.

Kuis

Kuis merupakan diberikan salah satu asesmen yang dilakukan dalam pembelajaran daring. Pemberian kuis bertujuan untuk: a) meningkatkan aktivitas belajar mahasiswa; b) melatih mahasiswa untuk berpikir cepat; c) meningkatkan pemahaman mahasiswa terhadap materi yang telah diberikan; d) menumbuh kembangkan sikap percaya diri siswa; e) menambah daya tarik pembelajaran dna motivasi belajar mahasiswa; dan f) sebagai salah satu tolok ukur pencapaian mahasiswa terhadap kemampuan akhir yang direncanakan pada setiap pokok bahasan. Dengan demikian, kuis diberikan pada setiap 2-3 pokok bahasan pada awal pembelajaran di pokok bahasan berikutnya.

Tugas

Tugas pada mata kuliah Teknik Analisis Data ini diberikan pada setiap akhir pokok bahasan, dimana semua tugas merupakan tugas individu/ mandiri/ independen. Sedangkan untuk tugas kolaboratif terakomodir dalam fasilitas Forum Diskusi, dimana pada setiap pokok bahasan mahasiswa diberi latihan soal untuk didiskusikan dengan teman satu kelasnya. Jumlah tugas sebanyak 9 tugas mandiri.

\section{Media Pembelajaran}

\section{Video Pembelajaran}

Video pembelajaran ini terdiri dari video yang dibuat oleh dosen pengampu dan video pembelajaran dari sumber lain yang dapat diakes melalui youtube. Video yang dibuat oleh dosen pengampu ini diskenario berdasarkan storyboard yang telah disusun. Dalam pembelajaran daring Teknik Analisis ini terdapat 3 video yaitu video materi Ukuran Pemusatan, video materi Uji-t dan video materi Regresi Linier. Sedangkan video pembelajaran oleh sumber lain (langsung diakses melalui youtube) disediakan pada setiap pokok bahasan. Video pembelajaran ini bertujuan untuk memudahkan mahasiswa dalam mempelajari materi, sehingga video ini bisa diunduh dan diakses kapan pun oleh mahasiswa.

\section{Gambar/Foto}


Laman LMS harus menarik dan interaktif, sehingga unsur gambar/foto sangat diperlukan untuk mendukung hal tersebut

\section{Sistem Penilaian}

\section{Bobot Penilaian}

Unsur-unsur yang dijadikan sebagai acuan penilaian selama masa pembelajaran (perkulahan) Teknik Analisis Data ini adalah:

a) Keaktifan dalam proses pembelajaran mandiri, dimana mahasiswa harus menggunakan berbagai cara yang memungkinkan untuk belajar, misalkan: a) belajar dari sumber referensi yang telah disediakan pada LMS; b) berbagai sumber yang dapat diakses melalui internet; 3) komunikasi intensif dengan sesama peserta didik ataupun dengan dosen pengampu melalui fasiltas forum atau chat pada LMS; dan 4) menghadiri sesi pertemuan virtual (online) bersama dosen pengampu;

b) Kehadiran dalam pertemuan tatap muka (offline);

c) Kedisiplinan dan kelengkapan dalam mengerjakan semua tugas yang diberikan melalui LMS;

d) Kedisilplinan dan kelengkapan dalam mengerjakan semua kuis yang diberikan melalui LMS;

e) Kedisiplinan dan kelengkapan dalam mengikuti Ujian Tengah Semester (UTS);

f) Kedisiplinan dan kelengkapan dalam mengikuti Ujian Akhir Semester (UAS).

\section{Kriteria Penilaian}

Berikut kriteria penilaian dalam pembelajaran daring Teknik Analisis Data disajikan dalam Tabel 3.

Tabel 3.

Kriteria Penilaian Pembelajaran Teknik Analisis Data

\begin{tabular}{|c|c|c|l|}
\hline Skor & Huruf & Angka Mutu & \multicolumn{1}{c|}{ Keterangan } \\
\hline $91-100$ & A & 4,00 & Interaksi yang lengkap dengan kualitas sangat baik \\
\hline $84-90$ & A- & 3,70 & Interaksi yang lengkap dengan kualitas baik \\
\hline $77-83$ & B + & 3,30 & Interaksi kurang lengkap dengan kualitas sangat baik \\
\hline $71-76$ & B & 3,00 & Interaksi kurang lengkap dengan kualitas baik \\
\hline $66-70$ & B- & 2,70 & Interaksi kurang lengkap dengan cukup baik \\
\hline $61-65$ & C + & 2,30 & Interaksi tidak lengkap dengan kualitas sangat baik \\
\hline $55-60$ & C & 2,00 & Interaksi tidak lengkap dengan kualitas baik \\
\hline $41-54$ & D & 1,00 & $\begin{array}{l}\text { Hanya terjadi sedikit interaksi dengan kualitas dengan } \\
\text { cukup baik }\end{array}$ \\
\hline$\leq 40$ & E & 0,00 & Hampir tidak ada interaksi sama sekali \\
\hline
\end{tabular}

Sumber: Analisis Peneliti

\section{Utilize Media And Materials (Memanfaatkan Media Dan Bahan Ajar)}

Setelah memilih metode, media, dan bahan ajar, langkah selanjutnya adalah menggunggah semua media dan bahan ke laman LMS STKIP PGRI Tulungagung dengan alamat https://vlearn.stkippgritulungagung.ac.id/. Setelah dilakukan penggunggahan, maka selanjutnya melakukan final checking terhadap keseluruhan konten e-learning laman LMS. Jika hasil dari final 
Pengembangan Multimedia Pembelajaran Statistika Berbasis ICT dengan Model Blended Project Based Learning, Maylita Hasyim

checking sudah lengkap maka semua konten e-learning siap untuk dilakukan validasi/ penilaian ahli yaitu ahli materi pembelajaran dan ahli media pembelajaran, untuk melihat kualitas dan kelayakan model yang telah dibuat. Tampilan konten LMS Mata Kuliah Teknik Analisis Data disajikan pada Gambar 3:

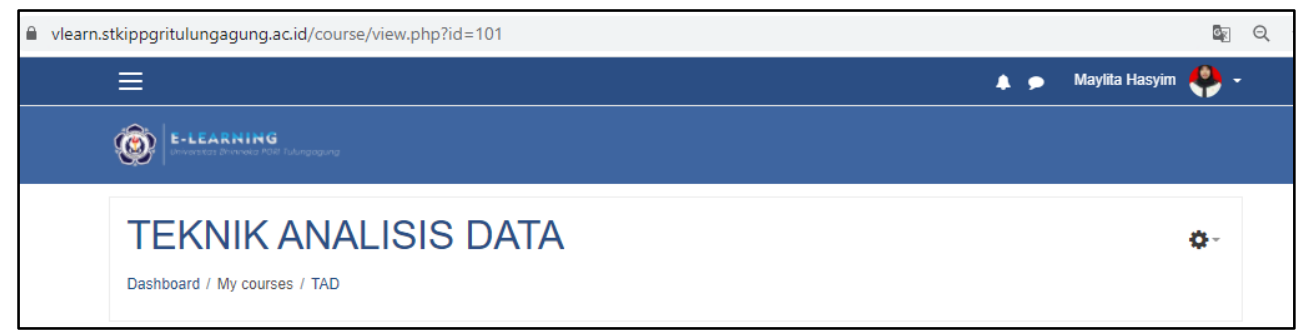

Gambar 3a. Tampilan LMS - Halaman Awal
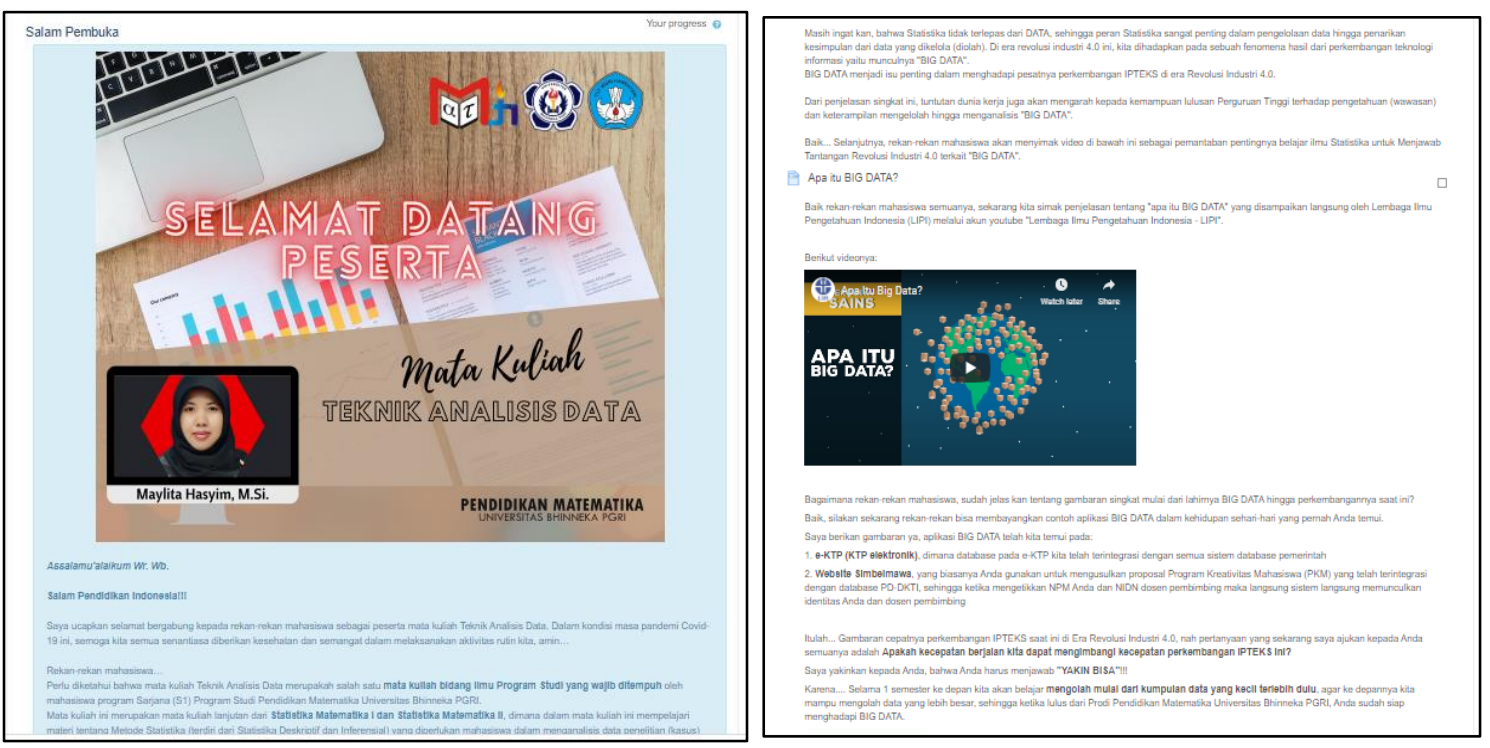

Gambar 3b. Tampilan LMS - Salam Pembuka

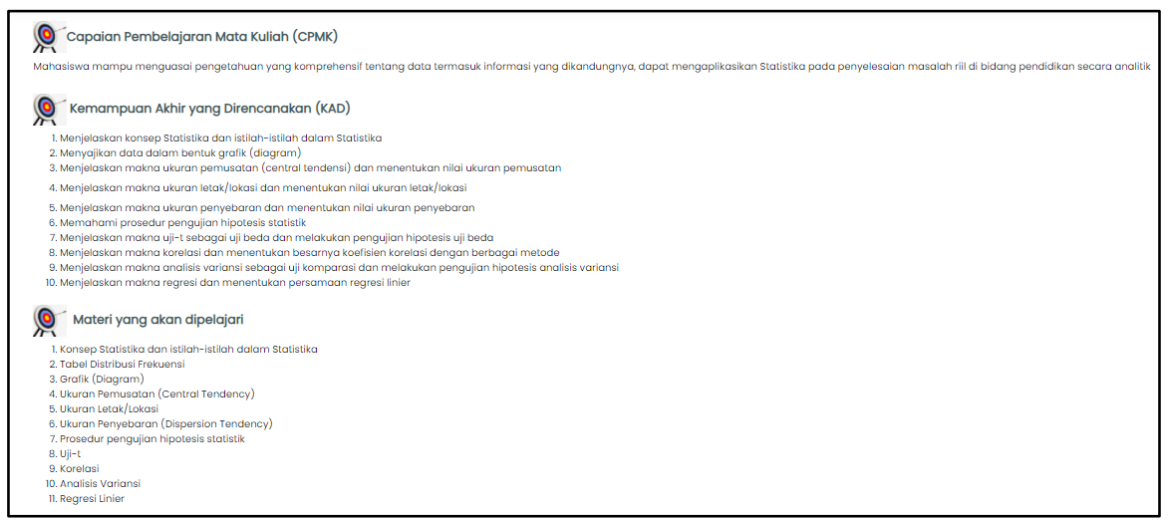

Gambar 3c. Tampilan LMS-CPMK, KAD dan Materi 

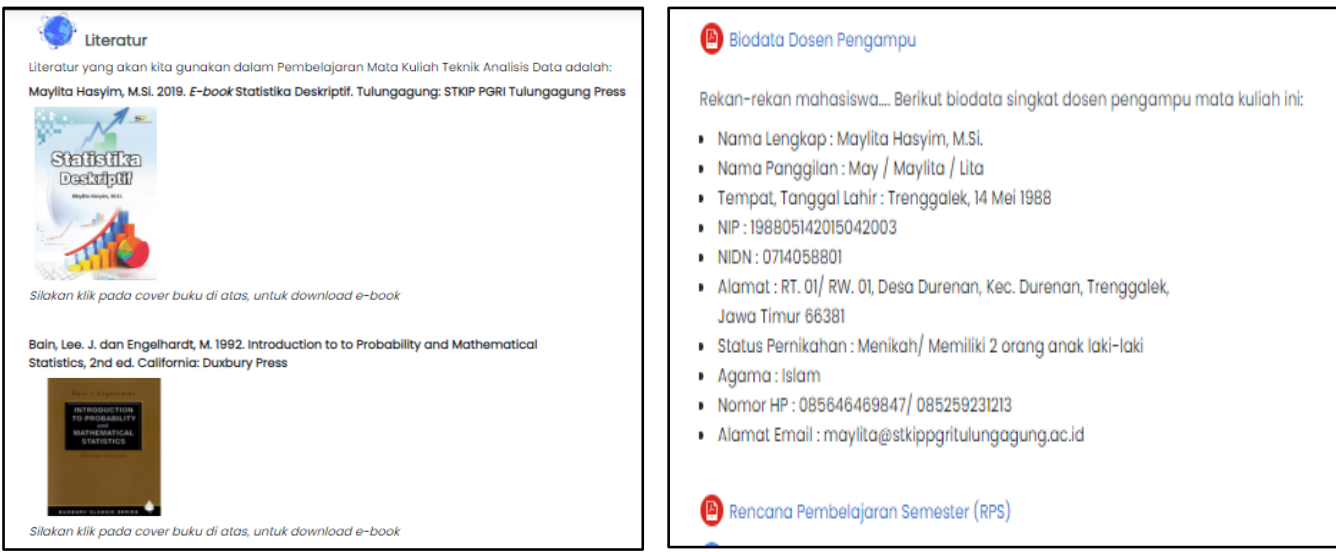

Gambar 3d. Tampilan LMS - Literatur, Biodata Dosen dan RPS

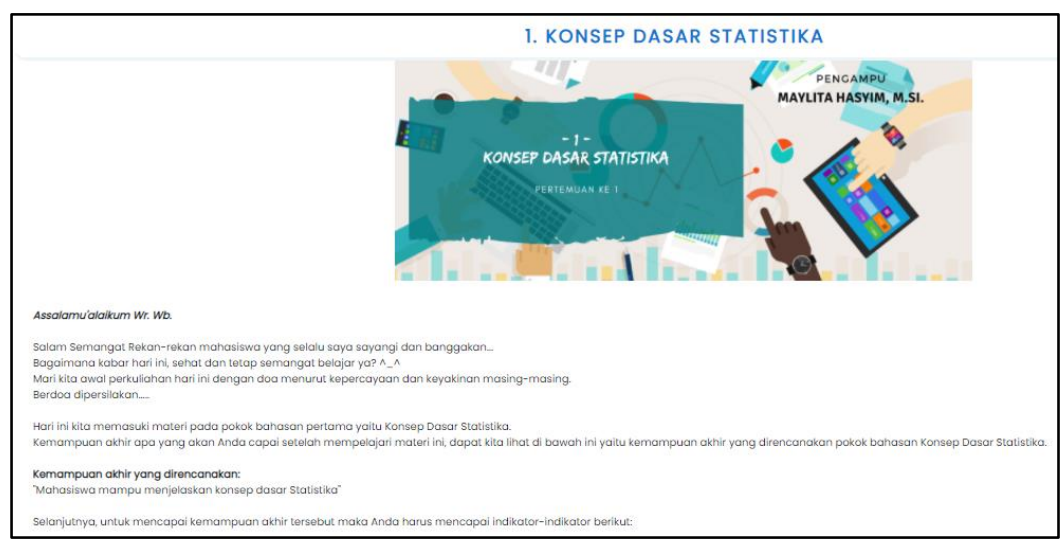

Gambar 3e. Tampilan LMS - Pembukaan untuk Pokok Bahasan 1

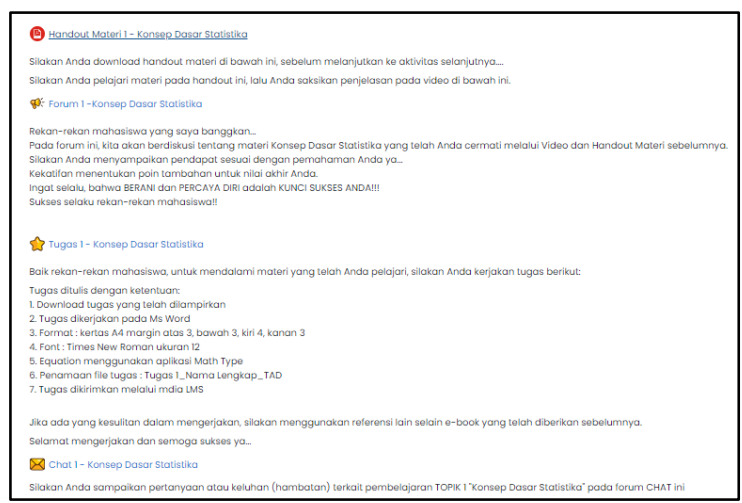

Gambar 3f. Tampilan LMS - Penyajian Materi, Forum Diskusi, Tugas dan Chat

Video 1 - Distribusi Frekuensi

Silakan rekan-rekan mahasiswa mencermati video penjelasan tentang Tabel Distribusi Frekuensi ini, sebelum Anda mengunduh materi

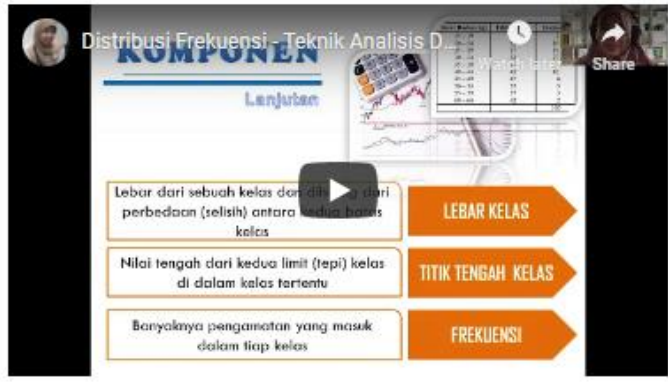

Gambar 3g. Tampilan LMS - Video Pembelajaran yang Dihasilkan Dosen Pengampu 
Ahli yang memvalidasi multimedia pembelajaran pada konten elearning mata kuliah Teknik Analisis Data adala ahli pembelajaran dan ahli media. Hasil validasi ahli terhadap multimedia pembelajaran Teknik Analisis Data telah menyatakan valid dan layak digunakan dalam pembelajaran dengan beberapa revisi. Skor dari lembar validasi dianalisis menggunakan Rumus 1, sehingga diperoleh Skor AP. Hasil Skor AP sebagai hasil validasi ahli disajikan pada Tabel 4.

Tabel 4.

Hasil Validasi Ahli terhadap Multimedia Pembelajaran pada Konten LMS

\begin{tabular}{|c|c|c|c|c|}
\hline Ahli & Skor AP & Indikator & Kategori & Hasil Validasi \\
\hline Media & $87 \%$ & $\geq 61 \%$ & Sangat Tinggi & Valid \\
\hline Materi & $84 \%$ & $\geq 61 \%$ & Sangat Tinggi & Valid \\
\hline
\end{tabular}

Berdasarkan kategori persentase pada Tabel 4, maka multimedia pembelajaran pada konten LMS Mata Kuliah Teknik Analisis Data dengan pendekatan model blended project based learning dapat dikatakan layak untuk diujicobakan kepada mahasiswa dan teman sejawat pada tahap uji kepraktisan.

\section{Require learner participation (melibatkan mahasiswa dalam kegiatan pembelajaran)}

Uji kepraktisan dilakukan dengan melihat hasil respon teman sejawat dan mahasiswa saat uji terbatas dalam mengakses multimedia pembelajaran yang terdapat pada konten LMS Mata Kuliah Teknik Analisis Data. Berikut hasil uji kepraktisan terhadap mahasiswa (mahasiswa semester 4) sebanyak 3 orang dan teman sejawat sebanyak 2 orang. Teman sejawat adalah dosen Prodi Pendidikan Matematika STKIP PGRI Tulungagung.

Tabel 5.

Hasil Uji Kepraktisan terhadap Multimedia Pembelajaran pada Konten LMS

\begin{tabular}{cccc}
\hline Penilai & Skor AP & Indikator & Kategori \\
\hline Mahasiswa 1 & $93 \%$ & $\geq 61 \%$ & Kepraktisan Sangat Tinggi \\
\hline Mahasiswa 2 & $87 \%$ & $\geq 61 \%$ & Kepraktisan Sangat Tinggi \\
\hline Mahasiswa 3 & $91 \%$ & $\geq 61 \%$ & Kepraktisan Sangat Tinggi \\
\hline Teman Sejawat 1 & $85 \%$ & $\geq 61 \%$ & Kepraktisan Sangat Tinggi \\
\hline Teman Sejawat 2 & $88 \%$ & $\geq 61 \%$ & Kepraktisan Sangat Tinggi \\
\hline
\end{tabular}

Berdasarkan kategori persentase pada Tabel 5, maka multimedia pembelajaran pada konten LMS Mata Kuliah Teknik Analisis Data dengan pendekatan model blended project based learning dapat dikatakan praktis dengan kategori Sangat Tinggi, sehingga multimedia sudah layak untuk digunakan dalam pembelajaran Teknik Analisis Data pada Semester Genap Tahun Akademik 2019/2020. 
Setelah model dan multimedia pembelajaran selesai dirancang dan dikembangkan, diujicobakan dan diterapkan dalam pembelajaran, langkah selanjutnya adalah melakukan evaluasi terhadap proses dan hasil implementasi. Langkah ini dilakukan untuk mendapatkan data terkait kekuatan dan kelemahan model dan multimedia yang dikembangkan. Pada tahap ini, beberapa revisi dilakukan pada struktur konten LMS yaitu: 1) urutan pemberian kuis dan forum diskusi; 2) pemilihan gambar/foto yang lebih beragam dan menarik; 3) sapaan untuk mahasiswa perlu ditambahkan. Revisi ini telah dilakukan pada konten LMS sehingga konten LMS Mata Kuliah Teknik Analisis Data dengan pendekatan model blended project based learning didapatkan model akhir yang siap digunakan secara luas.

\section{KESIMPULAN}

Berdasarkan hasil analisis data dan pembahasan, maka simpulan dari penelitian ini adalah:

1. Pengembangan multimedia pembelajaran Statistika Mata Kuliah Teknik Analisis Data Berbasis ICT dengan Model Blended Project Based Learning pada LMS STKIP PGRI Tulungagung menghasilkan 1) video pembelajaran sebanyak 3 video; 2) handout materi Statistika; dan 3) ebook ber-ISBN dengan judul "Statistika Deskriptif";

2. Menguji kelayakan materi dan produk multimedia pembelajaran Statistika Mata Kuliah Teknik Analisis Data Berbasis ICT dengan Model Blended Project Based Learning pada LMS STKIP PGRI Tulungagung. Hasil validasi ahli media dan ahli pembelajaran matematika menyatakan bahwa multimedia yang dihasilkan telah valid. Hasil penilaian teman sejawat dan mahasiswa menyatakan multimedia pembelajaran telah memenuhi aspek kepraktisan.

\section{DAFTAR PUSTAKA}

Dewi, Sinta, \& Verawat. (2016). Efektivitas penggunaan media Screencast O-Matic pada mata kuliah kalkulus integral terhadap hasil belajar mahasiswa. Jurnal Penelitian Pendidikan Dan Pengajaran Matematika, Vol. 2 No. 1 (2016) : 61-66.

Febrianto, Rais, M., \& Nurmila. (2017). Analisis Penerapan Media Pembelajaran Prezi Terhadap Hasil Belajar Siswa Kelas X TPHP Pada Mata Pelajaran Pengendalian Mutu Dalam Proses Pengolahan Di SMK Negeri 3 Takalar. Jurnal Pendidikan Teknologi Pertanian, Vol. 3, (2017): 42-48.

Haris Muhammad., \& Dudy Priatna. (2004). Media Massa dan Masyarakat Modern. Jakarta: Prenada Media.

Husamah. (2014). Pembelajaran Bauran (Blended Learning) Terampil Memadukan Keunggulan Pembelajaran Face-To-Face, E-learning Ofine-Online, dan Mobile Learning. Jakarta: Prestasi Pustaka.

Munir. (2010). Penggunaan Learning Management System (LMS) Di Perguruan Tinggi: Studi Kasus Di Universitas Pendidikan Indonesia. Cakrawala Pendidikan, Februari 2010, Th. XXIX, No. 1.

Priowirjanto, Yudha Prapantja dkk. (2013). Materi Simulasi Digital. Southeast Asian Minister of Education Organization Regional Open Learning Centre.

Raharja, Setya, Diat, P. L., \& Agung, N. A. (2011). Model Pembelajaran Berbasis Learning 
Management System Dengan Pengembangan Software Moodle Di SMA Negeri Kota Yogyakarta. Jurnal Kependidikan, Vol. 41 No. 1 Mei 2011, 55-70.

Sari, M. (2016). Blended Learning, Model Pembelajaran Abad Ke-21 Di Perguruan Tinggi. Ta'dib, Jurnal Fakultas Pendidikan Dan Pelatihan Guru, Universitas Batusangkar, Vol. 17(2), 126136.

Surasmi, W. A. (2016). Pemanfaatan Multimedia Untuk Mendukung Kualitas Pembelajaran. Prosiding Temu Ilmiah Nasional Guru (TING) VIII, Universitas Terbuka.

Surjono, H. D. (2017). Multimedia Pembelajaran Interaktif, Konsep dan Pengembangan. Yogyakarta: UNY Press.

Syafiudin, Sumarmi, M., \& Komang, A. I. (2016). Pengembangan Modul Geografi Pariwisata Dengan Project Based Learning Untuk Materi Ekowisata Pesisir Dan Laut Di Program Studi S1 Pendidikan Geografi Universitas Negeri Malang. Jurnal Pendidikan, Teori, Penelitian, Dan Pengembangan, Vol. 1 No. 3 Maret 2016, 347-353. 